\title{
Kemampuan Kerang Hijau (Perna viridis) Mengakumulasi Plutonium Melalui Jalur Air Laut
}

\section{The Ability of Green Mussels (Perna viridis) to Accumulate Plutonium Through Sea Water Pathway}

\author{
Budiawan $^{1 *}$, Nur Hidayati Febriana ${ }^{1}$, Heny Suseno ${ }^{2}$ \\ ${ }^{1}$ Departemen Kimia, Fakultas Matematika dan Ilmu Pengetahuan Alam, Universitas Indonesia \\ Kampus UI Depok, 16424, Indonesia \\ ${ }^{2}$ Pusat Teknologi Keselamatan dan Metrologi Radiasi (PTKMR), Badan Tenaga Nuklir Nasional \\ Lebak Bulus-Pasar Jumat, Jakarta Selatan, 12070, Indonesia \\ *Corresponding author: drbudiawanui@gmail.com
}

Receive: April 2018; Revision: March 2019; Accepted: April 2019; Available online: May 2019

\begin{abstract}
Abstrak
Operasional fasilitas nuklir yang ada di Serpong memungkinkan melepas radionuklida ke lingkungan. Isotop Pu merupakan radionuklida yang terlepas ke lingkungan. Lepasan tersebut terbawa oleh air sungai atau run off memasuki Teluk Jakarta. Kerang hijau (Perna viridis) mampu mengakumulasi radionuklida tersebut. Studi ini bertujuan untuk memahami kinetika proses bioakumulasi $\mathrm{Pu}$ oleh kerang hijau yang dipengaruhi oleh spesiasinya. Percobaan dilakukan melalui tahapan: aklimatisasi, bioakumulasi $\left({ }^{242} \mathrm{Pu}^{3+}\right.$ dan $\left.{ }^{242} \mathrm{Pu}^{4+}\right)$ dan depurasi. Parameter biokinetika diamati meliputi faktor konsentrasi $(\mathrm{CF})$, konstanta laju pengambilan $\left(\mathrm{k}_{\mathrm{u}}\right)$, konstanta laju pelepasan $\left(\mathrm{k}_{\mathrm{e}}\right)$, faktor biokonsentrasi (BCF), dan waktu paruh biologis $\left(\mathrm{t}_{b 1 / 2}\right)$. Berdasarkan uji statis non parametric menunjukkan spesiasi ${ }^{242} \mathrm{Pu}^{3+}$ dan ${ }^{242} \mathrm{Pu}^{4+}$ berpengaruh terhadap kemampuan Perna viridis mengakumulasi Pu. Rerata kemampuan bioakumulasi ${ }^{242} \mathrm{Pu}^{4+}$ oleh Perna viridis adalah 1,2 kali dibandingkan ${ }^{242} \mathrm{Pu}^{4+}$.
\end{abstract}

Kata kunci : Bioakumulasi, biokinetika, Perna viridis, plutonium, spesiasi, Perna viridis, plutonium.

\begin{abstract}
Operations of nuclear facilities in Serpong have potentially release radionuclides to environment. Pu isotope is one of radionuclide that is released into the environment. The release of this radionuclide was carried by the river water or run off entered the Bay of Jakarta. Green mussels (Perna viridis) can be accumulate this radionuclides. The aims of this study was to understand of the biokinetic of Pu bioaccumulation process by green mussels which are affected by its speciation. The experiment was carried out through stages: acclimatization, bioaccumulation $\left({ }^{242} \mathrm{Pu}^{3+}\right.$ and $\left.{ }^{242} \mathrm{Pu}^{4+}\right)$ and depuration. Biokinetic parameters was observed include concentration factor $(\mathrm{CF})$, uptake rate constant $\left(\mathrm{k}_{\mathrm{u}}\right)$, release rate constant $\left(\mathrm{k}_{\mathrm{e}}\right)$, bioconcentration factor $(\mathrm{BCF})$, and biological half-life $\left(\mathrm{t}_{\mathrm{b} 1 / 2}\right)$. Base on nonparametric statistic test shown that speciation of ${ }^{242} \mathrm{Pu}^{3+}$ and ${ }^{242} \mathrm{Pu}^{4+}$ had an effect on the ability of Perna viridis to accumulate Pu. Avarage of bioaccumulation capabilities of ${ }^{242} \mathrm{Pu}^{4+}$ by Perna viridis are 1.2 than ${ }^{242} \mathrm{Pu}^{3+}$.
\end{abstract}

Keywords: bioaccumulation, biokinetics, plutonium, Perna viridis, speciation.

DOI: $10.15408 / j k v \cdot v 5 i 1.7730$

\section{PENDAHULUAN}

Plutonium merupakan unsur radioaktif dengan nomor atom 94. Bentuk fisik plutonium berupa logam lunak berwarna putih keperakan yang perlahan-lahan akan kusam ketika berada pada udara kering dengan suhu 
kamar. Posisinya dalam tabel periodik masuk dalam golongan aktinida dan merupakan elemen unsur transuranium. Isotop ${ }^{239} \mathrm{Pu},{ }^{240} \mathrm{Pu}$ dan ${ }^{238} \mathrm{Pu}$ menunjukkan konsentrasi aktivitas yang signifikan di lingkungan. Semua isotop $\mathrm{Pu}$ memiliki waktu paruh yang relatif panjang. Plutonium diklasifikasikan sebagai radionuklida yang bersifat paling toksik diantara radionuklida ${ }^{90} \mathrm{Sr},{ }^{210} \mathrm{Po},{ }^{226} \mathrm{Ra}$ dan ${ }^{231} \mathrm{~Pa}$ (Powell et al., 2010).

Isotop utama yang paling dikenal saat ini adalah ${ }^{238} \mathrm{Pu},{ }^{239} \mathrm{Pu},{ }^{240} \mathrm{Pu}$, dan ${ }^{241} \mathrm{Pu}$. Peluruhan isotop ini terjadi dengan memancarkan partikel alfa, kecuali untuk ${ }^{241} \mathrm{Pu}$ yang meluruh dengan memancarkan partikel beta berenergi rendah. Peluruhan sebagian kecil fraksi ${ }^{236} \mathrm{Pu},{ }^{238} \mathrm{Pu},{ }^{240} \mathrm{Pu}$, dan ${ }^{242} \mathrm{Pu}$ terjadi dengan reaksi fisi spontan.

Sumber radionuklida plutonium diantaranya adalah isotop ${ }^{239} \mathrm{Pu}$ dan ${ }^{240} \mathrm{Pu}$. Kedua radioisotope tersebut masuk ke lingkungan laut dipengaruhi oleh pergerakan arus dunia yang melewati perairan laut Indonesia. Pergerakan arus tersebut dikenal dengan pola arus yang dinamakan Indonesian Throw Flow (ITF) yang membawa massa air dari perairan Samudera Pasifik melewati selat Makassar sebagai jalur utamanya (Suseno et al., 2015). Radioisotop plutonium dapat diakumulasi di dalam organ tubuh biota laut.

Bioakumulasi merupakan proses penumpukan suatu zat di dalam atau sebagian tubuh organisme. Bioakumulasi pada dasarnya merupakan gabungan dari dua proses yaitu bikonsentrasi dan biomagnifikasi (Suseno dan Panggabean, 2007). Biokonsentrasi adalah masuknya bahan pencemar secara langsung dari air oleh makhluk hidup melalui jaringan seperti insang atau kulit. Sedangkan bioakumulasi adalah masuknya bahan pencemar oleh makhluk hidup dari suatu lingkungan melalui suatu mekanisme atau lintasan. Sementara biomagnifikasi adalah proses dimana bahan pencemar konsentrasinya semakin meningkat dengan meningkatnya posisi makhluk hidup pada suatu rantai makanan (Suseno dan Panggabean, 2007; Suseno, 2015).

Kerang hijau (Perna viridis) adalah salah satu binatang lunak (Mollusca) yang banyak ditemui di Teluk Jakarta. Hewan ini populasinya yang cukup besar dan memiliki nilai ekonomis tinggi di perairan pesisir Indonesia (Suryono, 2013). Perna viridis bersifat sessile (menetap) hidup dengan cara menyaring material yang tersuspensi di perairan atau sedimen dan "non selective filter feeder" (sedikit bergerak).

Berbagai studi bioakumulasi dan distribusi ${ }^{242} \mathrm{Pu}$ oleh biota laut masih terbatas. Studi bioakumulasi plutonium kebanyakan dilakukan berdasar pemantauan lingkungan (Melinda et al., 2015). Wilson et al. (2009) melakukan eksperimen bioakumulasi untuk mengetahui konsentrasi radionuklida plutonium pada sampel plankton yang dikumpulkan di Laut Irlandia Timur. Berbagai studi menggunakan pendekatan biokinetik telah dilakukan (Mrabet et al., 2013; Strumińska-Parulska et al., 2011), disisi lain studi terkait bioakumulasi oleh kerang hijau masih sangat terbatas. Lebih lanjut kemampuan bioakumulasi juga ditentukan oleh spesiasi senyawaan tersebut.

Pada studi ini diamati pengaruh spesiasi Pu terhadap kemampuan bioakumulasi plutonium oleh Perna viridis berdasarkan pendekatan biokinetika. Kemampuan tersebut dibutuhkan untuk penilaian resiko dan untuk kepentingan food safety.

\section{METODE PENELITIAN Alat dan Bahan}

Alat yang digunakan adalah 6 akuarium berkapasitas \pm 4 liter, spectrometer alfa model dilengkapi dengan detektor model PIPS (Passivated Implanted Planar Silicon) beresolusi $20 \mathrm{keV}$, standar radiasi alfa, neraca analitik, pompa aerator, lampu, ice gel, coolbox, label kertas, plastik klip, nampan plastic, kertas merang, spidol, filter kapas dengan pori ukur $0,2 \mu \mathrm{m}$ dan $0,45 \mu \mathrm{m}$, akuarium kaca, plat stainless steel dan peralatan gelas lainnya.

Bahan yang digunakan selama penelitian berlangsung adalah air laut yang bebas kontaminan yang telah difiltrasi, biota laut Perna viridis, air destilasi, etanol, kista Artemia $s p$., perunut radionuklida ${ }^{242} \mathrm{Pu}^{3+}$ dan ${ }^{242} \mathrm{Pu}^{4+}$ dengan nilai aktivitas $74 \mathrm{~Bq} \cdot \mathrm{mL}^{-1}, \mathrm{HCl}$ pekat, $\mathrm{NH}_{2} \mathrm{OH} . \mathrm{HCl}, \mathrm{FeCl}_{3}, \mathrm{NaNO}_{2}, \mathrm{NH}_{4} \mathrm{OH}$ (1:1), $\mathrm{HNO}_{3}$ pekat, $\mathrm{HNO}_{3} 8 \mathrm{M}, \mathrm{NaNO}_{2}, \mathrm{H}_{2} \mathrm{SO}_{4}$ $5 \%$, indikator timol biru, $\mathrm{pH}$ indikator universal.

\section{Pengambilan Biota}

Kerang hijau (Perna viridis) diambil dari Muara Kamal di Teluk Jakarta pada tanggal 2 Oktober 2017. Perna viridis dibersihkan dari lumpur yang menempel di 
cangkangnya dan masih dalam keadaan menggerombol seperti anggur, kemudian diletakkan 4 ice gel di sekitar karung, supaya terjaga suhu tubuh Perna viridis saat berada di dalam perjalanan.

\section{Aklimatisasi}

Aklimatisasi adalah memberikan waktu adaptasi bagi organisme atau biota yang hidup di lingkungan penelitian dengan tujuan untuk mengurangi tingkat resiko kematian pada biota di saat awal pemeliharaan, sehingga nantinya biota yang digunakan tidak setres dan dapat digunakan dalam percobaan bioakumulasi. Perlakuan aklimatisasinya adalah Perna viridis dibersihkan dari hewan lain yang menempel dan ditempatkan secara terpisah pada akuarium air laut yang telah dipersiapkan sebelumnya. Sistem filtrasi dan airasi di dalam akuarium harus dipastikan bekerja dengan baik sehingga kualitas air dapat dipertahankan dan kandungan oksigen dalam air bagi biota tercukupi.

Aklimatisasi dilakukan dengan memelihara Perna viridis selama 7 hari tanpa pemberian kontaminan pada air akuarium. Penggantian air laut dalam akuarium dilakukan setiap hari di pagi hari. Selama proses aklimatisasi hewan percobaan diberikan pakan sehari dua kali yaitu berupa kista Artemia sp.

\section{Bioakumulasi ${ }^{242} \mathrm{Pu}^{3+} \mathrm{dan}^{242} \mathrm{Pu}^{4+}$ melalui Jalur Air Laut}

Setelah menjalani aklimatisasi, P.viridis dipindahkan ke dalam akuarium kaca berisi 2 liter air laut yang telah difiltrasi menggunakan filter $0.2 \mu \mathrm{m}$ pada $\mathrm{pH} 7$ lalu ditambahkan $1 \mathrm{~mL}$ perunut radioaktif ${ }^{242} \mathrm{Pu}^{+4}$ dengan aktivitas 0.74 Bq. $\mathrm{mL}^{-1}$. Dalam setiap akuarium tersebut ditempatkan 3 ekor Perna viridis, selama proses bioakumulasi hewan percobaan diberikan pakan sehari dua kali berupa Artemia sp.

Percobaan dilakukan secara seri untuk variasi waktu dan spesiasi. Pengambilan biota dari akuarium masing-masing 1 ekor dari tiap akuarium untuk ditimbang, diabukan dan dianalisis kandungan ${ }^{242} \mathrm{Pu}^{4+}$ dalam insang, organ pencernaan dan sisa untuk dapat dicacah menggunakan spektrometer alfa. Kemampuan bioakumulasi dinyatakan dalam CF (Faktor Konsentrasi) yaitu rasio kandungan $\mathrm{Pu}$ dalam biota $\left(\mathrm{C}_{\mathrm{t}}\right)$ dan air $\left(\mathrm{C}_{\mathrm{w}}\right)$.

$$
C F_{t}=\frac{C_{t}}{C_{w}}
$$

Pada saat kondisi kesetimbangan (steady state) dinyatakan dengan persamaan

$$
C F_{t}=C F_{s S}\left(1-e^{-k_{e} \cdot t}\right)
$$

Eksperimen dilakukan pengulangan sebanyak 3 kali

\section{Depurasi}

${ }^{242}{ }^{2+}$ Perna viridis yang mengandung melalui jalur air laut, dimasukkan masingmasing 2 ekor ke media air laut yang berisi air laut bebas kontaminan dan dalam kondisi air mengalir, serta lengkap dengan sistem filtrasi dan aerasi. Pemberian pakan pada Perna viridis tetap dilakukan sehari dua kali selama depurasi dan jenis pakan yang sama seperti sebelumnya, kemudian dianalisis kandungan ${ }^{242} \mathrm{Pu}^{4+}$ dan ${ }^{242} \mathrm{Pu}^{3+}$ dalam insang, pencernaan dan sisa organ Perna viridis dengan menggunakan spectrometer alfa. Nilai konstanta laju pelepasan $\left(\mathrm{k}_{\mathrm{e}}\right)$ diperoleh dari slope grafik persen (\%) aktivitas kontaminan teretensi terhadap waktu. Kemudian dihitung nilai BCF untuk mengetahui faktor konsentrasi bioakumulasi yang dapat dilihat pada persamaan di bawah ini.

$$
B C F=\frac{k_{u}}{k_{e}}
$$

Waktu paruh biologis Pu dalam tubuh kerang hijau dinyatakan oleh persamaan:

$$
\mathrm{t}_{\mathrm{b} 1 / 2}=\frac{\ln 2}{\mathrm{k}_{\mathrm{e}}}
$$

Eksperimen dilakukan pengulangan sebanyak 3 kali

\section{Preparasi dan Analisis Pu dalam Sampel Biota}

Prosedur preparasi dan analisis $\mathrm{Pu}$ dalam sampel biota mengacu pada Nakano \& Povinec (2012) yang telah dimodifikasi. Awal dari preparasi adalah dissection (pembedahan) dilakukan setelah uji bioakumulasi melalui jalur air laut, dissection diambil pada bagian insang, organ pencernaan dan sisa, lalu organ ditimbang, setelah itu diabukan dengan cara difurnace. 
Organ yang telah jadi abu siap untuk dilakukan analisis, abu kemudian dilarutkan dengan $\mathrm{HCl}$ pekat $5 \mathrm{~mL}$ ke dalam backer glass di atas hot plate pada suhu $200^{\circ} \mathrm{C}$, lalu ditambahkan $\mathrm{NH}_{2} \mathrm{OH} . \mathrm{HCl} 1 \mathrm{~mL}$, ditambahkan dengan $\mathrm{FeCl}_{3} 1 \mathrm{~mL}$, ditambahkan $\mathrm{NaNO}_{2} 1$ $\mathrm{mL}$. Setelah itu ditambah $\mathrm{NH}_{4} \mathrm{OH}$ (1:1) secara perlahan 6-7 tetes, lalu ditunggu sampai terbentuknya coklat granul yang mengendap, pisahkan endapan dengan larutan, endapan dimasukkan ke dalam backer glass, disaring menggunakan kertas saring, ambil filtratnya dan panaskan di atas hot plate sampai filtrat mendekati kering dengan suhu $350{ }^{\circ} \mathrm{C}$.

Setelah filtrat mendekati kering, ditambah HCI pekat, panaskan di atas hot plate sampai mendekati kering dengan suhu $350{ }^{\circ} \mathrm{C}$, ditambah $\mathrm{HNO}_{3}$ pekat $1 \mathrm{ml}$ lalu dipanaskan di atas hot plate sampai mendekati kering, $\begin{array}{llllllll}\text { ditambahkan } & \mathrm{HNO}_{3} & 8 & \mathrm{M} & 20 & \mathrm{ml} & \text { lalu }\end{array}$ ditambahkan $\mathrm{NaNO}_{2} 1 \mathrm{ml}$ panaskan mendekati kering, sampai timbul uap berwama putih dan ditunggu uap putihnya sampai menghilang, lalu ditambah $\mathrm{H}_{2} \mathrm{SO}_{4}$, ditambahkan timol biru \pm 5 tetes sambil backer glass digoyang sampai larutan berwarna pink, dititrasi dengan $\mathrm{NH}_{4} 0 \mathrm{H}$ (1:1) sambil backer glass digoyang sampai larutan sampel berwarna kuning jernih, lalu ditambahkan $\mathrm{H}_{2} \mathrm{SO}_{4}$ sampai larutan berwarna pink.

Larutan yang berwarna pink dipindahkan ke dalam sel elektrodeposisi, selanjutnya dielektrodeposisi dengan kondisi arus 2 amper, tegangan 10 volt, dan dalam waktu 2 jam. Plat stainless steel diambil, dicuci dengan aquades, plat stainless steel dikeringkan di dalam oven selama 2 menit dengan suhu $100{ }^{\circ} \mathrm{C}$. Kemudian diukur pada alpha spectrometer dengan menggunakan detektor PIPS (Passivated Implanted Planar Silicon).

\section{HASIL DAN PEMBAHASAN}

Bioakumulasi melalui jalur air laut merupakan keseimbangan antara dua proses yaitu pengambilan kontaminan dari medium air laut dan pelepasan kontaminan ke medium air laut (Rainbow, 2011). Pada studi ini menggunakan simulasi model yang dimodifikasi dari hasil eksperimen. Model kompartemen tunggal telah banyak digunakan untuk studi bioakumulasi radionuklida oleh beragam biota di perairan dengan berbagai penjelasan secara matematis pada kuantitas kontaminan (termasuk $\mathrm{Pu}$ ) sehingga dapat dijelaskan dengan laju pengambilan dan pelepasan dari tubuh biota (Dutton dan Fisher, 2011). Bioakumulasi menggunakan perunut radioaktif dengan memanfaatkan model kompartemen tunggal dapat digunakan pada saat studi bioakumulasi di laboraturium. Studi bioakumulasi dapat dilakukan secara terkontrol dan kontinyu dengan beragam konsentrasi dan simulasi kondisi biota di perairan (Suseno, 2015).

Pada studi ini digunakan Perna viridis yang mampu mengakumulasi kontaminan termasuk Pu. Tahapan pertama bioakumulasi $\mathrm{Pu}$ dimulai dari biosorpsi yang tidak melibatkan aktivitas enzimatik. Pada tahapan ini $\mathrm{Pu}$ berikatan secara reversible di permukaan sel P.viridis. Keseimbangan terjadi antara konsentrasi kedua kontaminan tersebut mengikuti prinsip - prinsip Langmuier dan berlangsung cepat. Tahapan berikutnya $\mathrm{Pu}$ berikatan dengan sisi reseptor protein pengangkut. Setelah berikatan dengan protein, $\mathrm{Pu}$ diangkut ke dalam membran sel. Pada saat berada di dalam membran sel, $\mathrm{Pu}$ dipindahkan ke berbagai organel sel untuk akumulasi. Tahapan ini berlangsung lambat dan melibatkan reaksi enzimatik (Rainbow, 2011).

Metabolisme Perna viridis Pu dimulai dengan bioabsorpsi kontaminan tersebut dari perairan ke dalam permukaan tubuh. Pada saat berada dalam perairan $\mathrm{Pu}$ dan Am berbentuk senyawa kompleks dengan ligan DOM (Dissolve Organic Metal). Disamping itu Pu juga membentuk senyawa kompleks dengan anion - anion $\left(\mathrm{Cl}^{-}, \mathrm{OH}^{-}, \mathrm{CO}_{3}{ }^{2-}, \mathrm{SO}_{3}{ }^{2-}\right)$ yang terkandung dalam air laut. Keragaman $\mathrm{Pu}$ dalam bentuk senyawaan kompleks menentukan bioavailabilitas, masing-masing spesi tersebut dalam absorpsi dan internalisasi ke dalam sel insang yang disebut aktive influx .

Pada penelitian ini dilakukan studi bioakumulasi radionuklida ${ }^{242} \mathrm{Pu}^{3+}$ dan ${ }^{242} \mathrm{Pu}^{4+}$ oleh Perna viridis yang diambil di sekitar perairan Teluk Jakarta. Wilayah perairan Teluk Jakarta menerima berbagai kontaminan baik logam berat, biologi maupun zat radioaktif. Dampak dari berbagai kegiatan operasional fasilitas nuklir yang berada di Serpong memungkinkan terlepasnya sejumlah radionuklida. Radionuklida yang terlepas mengalami disperse maupun spesiasi. 
Kemampuan akumulasi ${ }^{242} \mathrm{Pu}^{3+}$ dan ${ }^{242} \mathrm{Pu}^{4+}$ oleh kerang hijau ditunjukkan pada Gambar 1 dan 2.

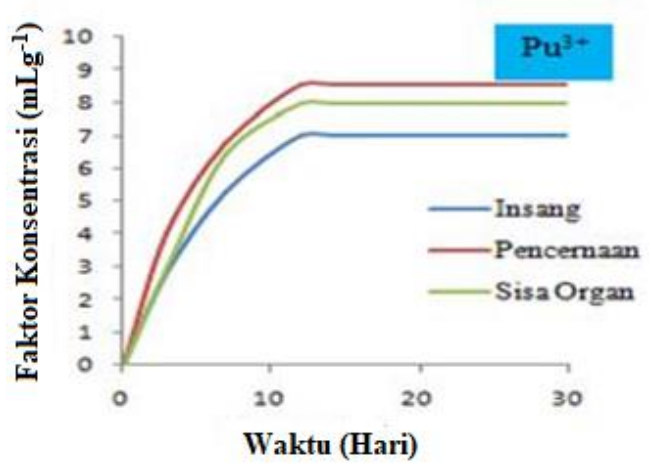

Gambar 1. Faktor Konsentrasi ${ }^{242} \mathrm{Pu}^{3+}$

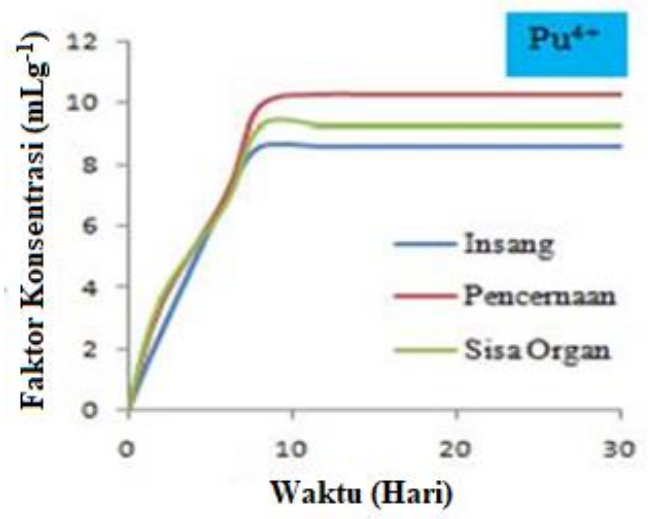

Gambar 2. Faktor Konsentrasi ${ }^{242} \mathrm{Pu}^{4+}$

Gambar 1 dan 2 menunjukkan perbandingan nilai Faktor Konsentrasi (CF) untuk ${ }^{242} \mathrm{Pu}\left(\mathrm{Pu}^{3+}\right.$ dan $\left.\mathrm{Pu}^{4+}\right)$. Nilai $\mathrm{CF} \mathrm{Pu}^{3+}$ pada insang, pencernaan dan sisa organ berturut-turut sebesar 0 sampai dengan $7.0 \mathrm{~mL} \cdot \mathrm{g}^{-1}, 0$ sampai dengan $8.8 \mathrm{~mL} \cdot \mathrm{g}^{-1}, 0$ sampai dengan $8.0 \mathrm{~mL} \cdot \mathrm{g}^{-1}$ dengan kisaran waktu dari hari ke-0 sampai dengan 12. Nilai $\mathrm{CF} \mathrm{Pu}^{4+}$ pada insang, pencernaan dan sisa organ berturut-turut sebesar 0 sampai dengan $8.8 \mathrm{~mL} . \mathrm{g}^{-1}, 0$ sampai dengan $10.4 \mathrm{~mL} \cdot \mathrm{g}^{-1}, 0$ sampai dengan $9.8 \mathrm{~mL} \cdot \mathrm{g}^{-1}$ dengan kisaran waktu dari hari ke-0 sampai dengan 12. Namun demikian, nilai $\mathrm{CF}_{\mathrm{ss}}$ adalah CF pada saat kondisi steady state dan tercapai setelah hari ke-12. Miramand dan Germain, (2013) menjelaskan bahwa nilai steady state pada hewan moluska (species kerang) yaitu pada hari ke -28 Perbedaan nilai steady state. Perbedaan nilai steady state tersebut disebabkan oleh jenis spesiasi $\mathrm{Pu}$ yang digunakan, sifat kimia fisika perairan dan spesies biota yang digunakan. Setiap biota laut memiliki kemampuan mengakumulasi Pu yang berbeda beda. Hal ini dikarenakan perbedaan sistem metabolisme setiap biota laut.

Proses pengambilan kontaminan tidak semata proses absorpsi maupun difusi. Proses pengambilan tersebut melalui transpor aktif dimana dalam hal ini melibatkan pompa $\mathrm{Na}-\mathrm{K}$, eksositosis dan endositosis. Transpor ini memerlukan energi (ATP), tidak dipengaruhi oleh gradien konsentrasi Pu di dalam air laut. Arah perpindahan $\mathrm{Pu}$ sesuai kebutuhan. Pompa $\mathrm{Na}-\mathrm{K}$ berfungsi mengatur muatan listrik sitosol sel syaraf dan sel otot dengan lingkungan. Transpor aktif berfungsi memberikan efek terjadinya aliran impuls atau gelombang potensial aksi pada membran sel syaraf dan sel otot dalam meyampaikan informasi (Bustamante et al., 2012). Rekapitulasi kemampuan mengaku-mulasi ditunjukkan pada Tabel 1.

Tabel 1. Rekapitulasi Pengambilan $\mathrm{Pu}^{3+}$ dan $\mathrm{Pu}^{4+}$ oleh Perna viridis melalui Jalur air laut

\begin{tabular}{lll}
\hline Spesi Pu & Organ Tubuh $\boldsymbol{P}$. viridis & CF $\left(\mathbf{m L} \cdot \mathbf{g}^{\mathbf{1}}\right)$ \\
\hline $\mathrm{Pu}^{3+}$ & Insang & $7.0 \pm 0.8$ \\
& Pencernaan & $8.8 \pm 0.9$ \\
& Sisa & $8.0 \pm 0.7$ \\
\hline $\mathrm{Pu}^{4+}$ & Insang & $8.8 \pm 0.9$ \\
& Pencernaan & $10.4 \pm 1.1$ \\
& Sisa & $9.8 \pm 1.0$ \\
\hline
\end{tabular}

Berdasarkan hasil eksperimen nilai $\mathrm{CF}$ ${ }^{242} \mathrm{Pu}\left(\mathrm{Pu}^{3+}\right.$ dan $\left.\mathrm{Pu}^{4+}\right)$ yang ditunjukkan pada Tabel 1, menunjukkan nilai $\mathrm{CF}$ isotop $\mathrm{Pu}^{3+}$ dan $\mathrm{Pu}^{4+}$ terakumulasi lebih banyak pada organ pencernaan dan paling sedikit pada organ insang. Perna viridis adalah salah satu biota laut yang mudah menyerap logam berat dari air laut, salah satunya logam $\mathrm{Pu}$ yang dapat terakumulasi pada saluran pencernaan (kelenjar pencernaan atau hepatopankreas). 
Nilai $\mathrm{k}_{\mathrm{u}} \mathrm{Pu}^{3+}$ dan $\mathrm{Pu}^{4+}$ dapat dilihat dari slope hari pertama sampai dengan hari ke-12.

Isotop $\mathrm{Pu}$ yang dilepas oleh insang terbawa oleh aliran darah menuju jaringanjaringan lunak, kemudian masuk ke dalam organ pencernaan. Hal ini diduga logam $\mathrm{Pu}$ lebih banyak terdistribusi di dalam organ pencernaan. Menurut (Wang dan Lu, 2017) metallothionein dapat mengikat logam berat didalam organ pencernaan moluska. Molekul dari metallothionein bersifat ringan dan mudah larut (Cytosolid). Bagian dari metallothionein berupa thiol yang kaya protein karena mengandung asam amino yang mampu berikatan dengan logam berat. Metallothionein didistribusikan secara meluas ke seluruh organ tubuh species kerang Mytillus Gallop seperti pada gills, mantel dan kelenjar pencernaan. Pengambilan kontaminan ${ }^{242} \mathrm{Pu}\left(\mathrm{Pu}^{3+}\right.$ dan $\mathrm{Pu}^{4+}$ ) pada organ insang dan sisa lebih lambat dibadingkan dengan organ pencernaan. Hal ini diduga dikarenakan di dalam organ insang metallothionein lebih sedikit kandungannya dibandingan dengan organ pencernaan. Dalam air laut pada kondisi tidak terkompleks Pu (III) dan Pu (IV) berada dalam ion hidrat. Molekul air melingkupi logam tersebut sehingga oksigen dalam senyawaan $\mathrm{Pu}$ tersebut membentuk ikatan hidrogen dengan oksigen pada protein (Clark, 2010). Pada organ pencernaan terbentuk senyawaan organo plutonium dimana $\mathrm{Pu}$ berbentuk sandwich dengan protein maupun methallotionein (Clark, 2010). Gambar 3 dibawah ini menunjukkan ikatan hidrogen dalam senyawaan $\mathrm{Pu}$.

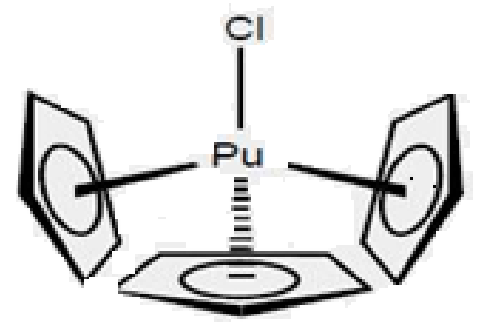

Gambar 3. Ikatan hidrogen dalam senyawa $\mathrm{Pu}(\mathrm{\eta}$ $\left.\mathrm{C}_{5} \mathrm{H}_{5}\right)_{3} \mathrm{Cl}$ (Clark, 2010)

Pelepasan kontaminan (depurasi) adalah proses eksositosis yang merupakan pemindahan molekul dari dalam sel ke lingkungan. Pengeluaran tersebut dilakukan oleh sebuah vesikel (kantong) yang berselaputkan membran (umumnya berasal dari badan golgi). Membran vesikel akan bersatu dengan membran sel, sehingga molekul di dalam vesikel akan keluar dari sel (Bustamante et al., 2012). Pengomplekan merupakan salah satu dari mekanisme detoksifikasi utama. Dalam tubuh biota laut terdapat ligan yang memiliki afinitas yang tinggi seperti phytochelatin dan metallothionein. Kedua ligan tersebut terdapat di semua sel biota laut dan mempunyai kemampuan mengikat logam berat (termasuk $\mathrm{Pu}$ ) (Rainbow, 2011).

Phytochelatin dan metallothionein memiliki perbedaan pada molekul protein pengikat logam berat. Phytochelatin bersifat enzimatik pada peptida yang disintesis, sedangkan metallothionein adalah polipeptida yang dikodekan oleh gen. Phytochelatin adalah polipeptida dengan struktur (-Glu-Cys) nGly(di mana $\mathrm{n}=2-11$ ) dan dapat disintesis dengan dari senyawaan glutathione (GSH) dengan bantuan enzim phytochelatin synthase (PCS). Glutathione (GSH) oleh gen phytochelatin synthase (PCS) secara luas dikenal untuk chelate logam berat. Selain itu, phytochelatin berperan penting dalam detoksifikasi logam berat dengan cara mengangkut logam berat menuju ke bagian vakuola (Dummee et al., 2012). Metallothionein juga termasuk polipeptida Cys dimana metallothionein terdapat dalam berbagai jenis biota laut kekerangan (Dummee et al., 2012). Metallothionein sel tubuh biota laut sangat berperan penting dalam menjaga homoeostasis esensial logam transisi dan detoksifikasi logam berat yang beracun. Berikut ini merupakan hasil eksperimen depurasi radionuklida $\mathrm{Pu}$ oleh Perna viridis ditunjukkan pada Gambar 4.

Tahapan depurasi yaitu depurasi cepat dan depurasi lambat pada Pu. Depurasi cepat $\mathrm{Pu}$ adalah proses pelepasan kontaminan yang menunjukkan $\mathrm{Pu}$ terlepas lebih cepat pada masing-masing organ sasaran ketika kontaminan berkurang dari lingkungan perairan. Pada kurva garis menunjukkan gradien penurunan tinggi pada depurasi cepat Pu selama 3 hari dari hari ke-1 sampai hari ke3. Depurasi lambat $\mathrm{Pu}$ adalah proses pelepasan kontaminan yang menunjukkan $\mathrm{Pu}$ yang teretensi kuat pada masing-masing organ sasaran. Pada kurva garis menunjukkan gradien penurunan rendah yaitu pada hari ke-4 sampai hari ke-7. Pada Tabel 2 menyajikan rekapitulasi pelepasan Pu dari Perna viridis. 


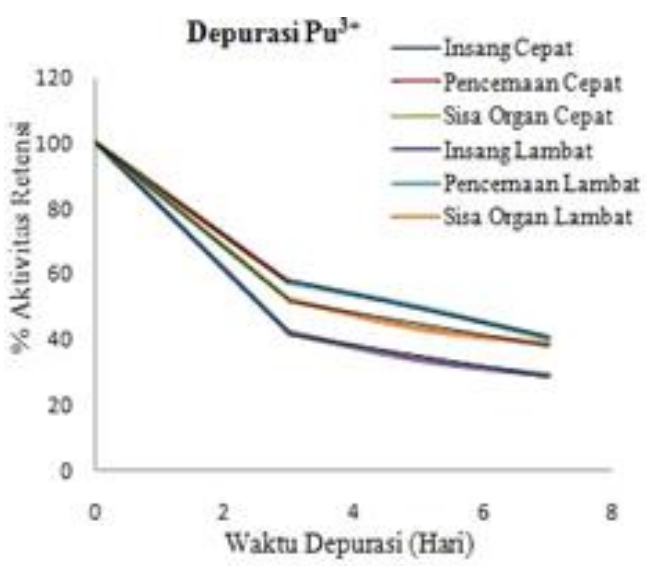

Gambar 4. Pelepasan/depurasi $\mathrm{Pu}^{3+}$

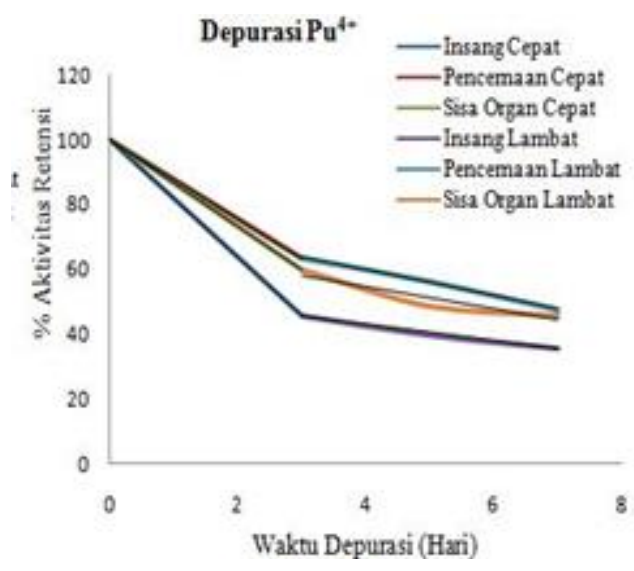

Gambar 5. Pelepasan/depurasi $\mathrm{Pu}^{4+}$

Tabel 2. Rekapitulasi pelepasan $\mathrm{Pu}^{3+}$ dan $\mathrm{Pu}^{4+}$

\begin{tabular}{clllll}
\hline Spesi & \multicolumn{1}{c}{ Organ } & \multicolumn{1}{c}{$\mathbf{C F}\left(\mathbf{m l .} \mathbf{g}^{-\mathbf{1}}\right)$} & $\mathbf{K}_{\mathbf{u}}\left(\mathbf{m l . g}^{-\mathbf{1}} \cdot \mathbf{h a r i}^{-\mathbf{1}}\right)$ & \multicolumn{2}{c}{$\mathbf{K}_{\mathbf{e}}\left(\mathbf{h a r i}^{-\mathbf{1}}\right)$} \\
\hline $\mathrm{Pu}^{2+}$ & Insang & $7.0 \pm 0.8$ & $0.205 \pm 0.019$ & $0.192 \pm 0.018$ & $0.033 \pm 0.002$ \\
& Pencernaan & $8.8 \pm 0.9$ & $0.241 \pm 0.025$ & $0.142 \pm 0.015$ & $0.043 \pm 0.004$ \\
& Sisa & $8.0 \pm 0.7$ & $0.236 \pm 0.029$ & $0.159 \pm 0.016$ & $0.034 \pm 0.003$ \\
$\mathrm{Pu}^{3+}$ & Insang & $8.8 \pm 0.9$ & $0.239 \pm 0.028$ & $0.181 \pm 0.019$ & $0.025 \pm 0.003$ \\
& Pencernaan & $10.4 \pm 1.1$ & $0.294 \pm 0.03$ & $0.122 \pm 0.013$ & $0.034 \pm 0.003$ \\
& Sisa & $9.8 \pm 1.0$ & $0.253 \pm 0.03$ & $0.135 \pm 0.013$ & $0.035 \pm 0.003$ \\
\hline
\end{tabular}

Berdasarkan Tabel 2 tersebut, $\mathrm{Pu}^{3+}$ dilepas secara cepat $(50 \%)$ oleh Perna viridis paling besar pada organ pencernaan. Hal serupa ditunjukkan pada pelepasan cepat $\mathrm{Pu}^{4+}$. Di sisi lain $\mathrm{Pu}^{3+}$ dilepas secara lambat pada organ insang (5\%). Hal serupa ditunjukkan pada pelepasan lambat $\mathrm{Pu}^{4+}$.Sedangkan $\mathrm{Pu}^{3+}$ dilepas secara cepat pada organ pencernaan (65\%). Hal serupa ditunjukkan pada pelepasan cepat $\mathrm{Pu}^{4+}$. Di sisi lain $\mathrm{Pu}^{3+}$ dilepas secara lambat pada organ insang (7\%). Hal serupa ditunjukkan pada pelepasan lambat $\mathrm{Pu}^{4+}$. Faktor internal adalah kapasitas akuumulasi yang dimiliki oleh Perna viridis berupa sisi aktif membran sel yang berfungsi sebagai bioligan pengikat logam berat (Bustamante et al., 2012). Faktor internal tersebut berdasarkan ukuran biota Perna viridis, sistem kerja enzim di dalam tubuh biota dan kemampuan biota pada saat melepaskan kontaminan. Faktor eksternal berdasarkan kondisi kimia fisik perairan, jenis kontaminan, spesiasi kontaminan dan spesies biota yang digunakan. Faktor eksternal tersebut dapat menentukan bioavailability $\mathrm{Pu}$ dalam berbagai bentuk senyawaannya. Plutonium dan americium akan berikatan dengan ligan pada sisi aktif membran sel (Clark, 2010). Uji statistic menggunakan metoda non parametric (uji Mann Whitney) menunjukkan terdapat perbedaan kemampuan Perna viridis mengakumulasi $\mathrm{Pu}^{3+}$ dan $\mathrm{Pu}^{4+}$.

\section{SIMPULAN}

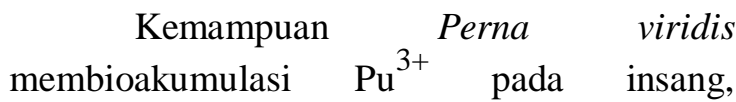
pencernaan dan sisa organ berturut-turut sebesar $7.0 \mathrm{~mL} . \mathrm{g}^{-1} ; 8.8 \mathrm{~mL} . \mathrm{g}^{-1}$ dan $8.0 \mathrm{~mL} \cdot \mathrm{g}^{-1}$. Pada $\mathrm{CF} \mathrm{Pu}^{4+}$ pada insang, pencernaan dan sisa organ berturut-turut sebesar $8.8 \mathrm{~mL} . \mathrm{g}^{-1}$; $10.4 \mathrm{~mL} \cdot \mathrm{g}^{-1}$ dan $9.8 \mathrm{~mL} \cdot \mathrm{g}^{-1}$. Kecepatan pengambilan $\left(\mathrm{k}_{\mathrm{u}}\right) \mathrm{Pu}^{3+}$ berturut-turut pada insang, pencernaan dan sisa organ adalah 0.205 hari $^{-1} ; 0.241$ hari $^{-1} ; 0.236$ hari $^{-1}$. Nilai $\mathrm{k}_{\mathrm{u}}$ $\mathrm{Pu}^{4+}$ masing-masing pada insang, pencernaan dan sisa organ adalah 0.239 hari $^{-1} ; 0.294$ hari $^{-1}$; 0.253 hari $^{-1}$. Laju pelepasan cepat $\left(\mathrm{k}_{\mathrm{e} 1}\right) \mathrm{Pu}^{3+}$ masing-masing pada organ insang, pencernaan dan sisa organ adalah 0.1927 hari $^{-1} ; 0.1418$ hari $^{-1} ; 0.1586$ hari $^{-1}$. Laju pelepasan lambat $\left(\mathrm{k}_{\mathrm{e} 2}\right) \mathrm{Pu}^{3+}$ masing-masing pada organ insang, pencernaan dan sisa organ adalah 0.0331 hari ${ }^{1} ; 0.0426$ hari $^{-1} ; 0.0343$ hari $^{-1}$. Laju pelepasan cepat $\left(\mathrm{k}_{\mathrm{e} 1}\right) \mathrm{Pu}^{4+}$ masing-masing pada organ insang, pencernaan dan sisa organ adalah 
0.181 hari $^{-1} ; 0.1215$ hari $^{-1} ; 0.135$ hari $^{-1}$. Laju pelepasan lambat $\left(\mathrm{k}_{\mathrm{e} 2}\right) \mathrm{Pu}^{4+}$ berturut-turut pada organ insang, pencernaan dan sisa organ adalah 0.0250 hari $^{-1} ; 0.0399$ hari $^{-1} ; 0.0354$ hari $^{-}$ 1. Isotop $\mathrm{Pu}^{3+}, \mathrm{Pu}^{4+}$ terakumulasi terbesar pada organ pencernaan dan sedikit terakumulasi pada organ insang. Berdasarkan hasil yang diperoleh maka Perna viridis dapat digunakan sebagai bioindikator kontaminan $\mathrm{Pu}$.

\section{UCAPAN TERIMAKASIH}

Terimakasih disampaikan kepada Dr. Wahyu Retno Prihatiningsih yang telah membantu pekerjaan ini.

\section{DAFTAR PUSTAKA}

Bustamante P, Luna-Acosta A, Clemens S, Cassi R, Thomas-Guyon H, Warnau M. 2012. Bioaccumulation and metabolisation of 14C-pyrene by the Pacific oyster Crassostrea gigas exposed via seawater. Chemosphere. $\quad 87(8)$ : 938-944. http://doi.org/10.1016/j.chemosphere. 2012 .01 .049

Clark DL. 2010. The Chemical Complexities of Plutonium. In Plutonium Chemistry (pp. 366- 381). Los Alamos Science. http://doi.org/10.1103/PhysRevB.70.0854 18.

Dummee V, Kruatrachue M, Trinachartvanit W, Tanhan P, Pokethitiyook P, Damrongphol P. 2012. Bioaccumulation of heavy metals in water, sediments, aquatic plant and histopathological effects on the golden apple snail in Beung Boraphet reservoir, Thailand. Ecotoxicology and Environmental Safety. 86 204-212. http://doi.org/10.1016/j.ecoenv.2012.09.01 8

Dutton J, Fisher NS. 2011. Bioaccumulation of As, $\mathrm{Cd}, \mathrm{Cr}, \mathrm{Hg}(\mathrm{II})$, and $\mathrm{MeHg}$ in killifish (Fundulus heteroclitus) from amphipod and worm prey. Science of the Total Environment. 409(18): 3438-3447. http://doi.org/10.1016/j.scitotenv.2011.05. 022 .

Melinda K, Suseno H, Prihatini W. 2015. Bioaccumulation and distribution of 137 Cesium in the Humpback Grouper Fish (Cromileptes altivelis). Nusantara Bioscience. $\quad 7(2)$ : 180-184. http://doi.org/10.13057/nusbiosci/n070221
Miramand P, Germain P. 2013. Sea water uptake, sediment transfer and histoautoradiographic study of plutonium $\left({ }^{239} \mathrm{Pu}\right)$ and americium $\left({ }^{241} \mathrm{Am}\right)$ in the edible cockle Cerastoderma edule. Marine Ecology Progress Series. 22(1):59-68.

Mrabet REL, Abril JM, Manjo G. 2013. Experimental and modelling study of plutonium uptake by suspended matter in. Water Res. 35(17): 4184-4190.

Nakano M, Povinec PP. 2012. Long-term simulations of the ${ }^{137} \mathrm{Cs}$ dispersion from the Fukushima accident in the world ocean. Journal of Environmental Radioactivity. 111(2012): 109-115. http://doi.org/10.1016/j.jenvrad.2011.12.0 01 .

Powell BA, Fjeld RA, Coates JT. 2010. Plutonium Oxidation State Geochemistry in the SRS Subsurface Environment. South Carolina (US): Westinghouse Savannah River Company, Aiken, SC.

Rainbow PS. 2011. Trace metal bioaccumulation: Models, metabolic availability and toxicity. Environment International. 33(4): $\quad$ 576-582. http://doi.org/10.1016/j.envint.2011.05.00 8.

Strumińska-Parulska DI, Skwarzec B, Fabisiak J. 2011. Plutonium bioaccumulation in seabirds. Journal of Environmental Radioactivity. 102(12): 1105- 1111. http://doi.org/10.1016/j.jenvrad.2011.07.0 02.

Suryono, C. A. (2013). Filtrasi kerang hijau Perna viridis terhadap micro algae pada media terkontaminasi logam berat. J. Buletin Oseanografi Marina. 2(1): 41-47.

Suseno H. 2015. Capability of Catfish (Clarias gariepinus) to Accumulate $\mathrm{Hg}^{2+}$ From Water. Aceh International Journal of Science and Technology. 4(3): 93-98. http://doi.org/10.13170/aijst.4.3.3018.

Suseno H, Panggabean SM. 2007. Merkuri: spesiasi dan bioakumulasi. Jurnal Teknologi Pengelolaan Limbah(Journal of Waste Management Technology). 10(1): 66-78.

Suseno H, Wahono IB, Muslim. 2015. Radiocesium monitoring in Indonesian waters of the Indian Ocean after the Fukushima nuclear accident. Marine Pollution 
Bulletin. $\quad$ 97(1-2): 539543http://doi.org/10.1016/j.marpolbul.201 5.05.015.

Wang W, Lu G. 2017. Heavy Metals in Bivalve Mollusks. $\quad$ Elsevier Ltd. http://doi.org/10.1016/B978-0-08-1006740.00021-7.
Wilson RC, Watts SJ, Vives IBJ, McDonald P. 2009. Laboratory and field studies of polonium and plutonium in marine plankton. Journal of Environmental Radioactivity. 100(8): 665669.http://doi.org/10.1016/j.jenvrad.2009. 05.007. 